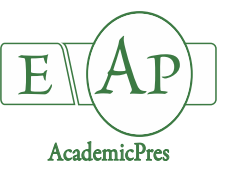

Guerra-Ramirez D et al. (2021)

Notulae Botanicae Horti Agrobotanici Cluj-Napoca

Volume 49, Issue 1, Article number 11988

DOI: $10.15835 /$ nbha49111988

Research Article

\title{
Antioxidants in processed fruit, essential oil, and seed oils of feijoa
}

\author{
Diana GUERRA-RAMÍREZ ${ }^{1}$, Karla E. GONZÁLEZ-GARCÍA", \\ Jessica M. MEDRANO-HERNÁNDEZ ${ }^{1}$, Franco FAMIANI ${ }^{2}$, \\ Juan G. CRUZ-CASTILLO ${ }^{3 *}$
}

\author{
${ }^{1}$ Universidad Autónoma Chapingo, Km. 38.51 Carr. México-Texcoco, Chapingo, Estado de México, CP 56230, \\ Mexico;dguerrar@chapingo.mx; karlitauv@gmail.com; yesimirme@gmail.com \\ ${ }^{2}$ Università degli Studi di Perugia, Dipartimento di Scienze Agrarie e Ambientali, 06121 Perugia, Italy; franco.famiani@unipg.it \\ ${ }^{3}$ Universidad Autónoma Chapingo, Centro Regional Universitario Oriente, Huatusco, Veracruz, CP 94100 , \\ Mexico; jcruzc@chapingo.mx (*corresponding author)
}

\begin{abstract}
The degradation of nutraceutical properties during processing of the fruits of feijoa (Acca sellowiana), and the characterization of seed oils, and volatile compounds were evaluated. In feijoa fruit dehydrated by a standard convective air process, the total phenols and total flavonoids declined $42 \%$, and the antioxidant capacity determined by ABTS, DPPH, and FRAP declined $26 \%$ with respect to lyophilized fruit. In feijoa jam, the reduction of total phenols and flavonoids was $52 \%$, and the reduction in antioxidant capacity was $72 \%$. Vitamin $C$ in the jam was also reduced by the processing. Feijoa seeds had $69.4 \%$ unsaturated fatty acids, mainly linoleic (46.2\%) and linolenic (3.7\%) acids. Behenic acid was also detected in the seeds but in small amounts (0.91\%). The feijoa skin had 31 volatile compounds in two orchards with different climate, one in a tropical highland and the other in a temperate zone. The extraction yield was on average $0.45 \%$. The major compounds in the essential oil of the feijoa skin were 3-hexen-1-yl benzoate, elixene, spathulenol, D-germacrene and alphacadinol. In general, the concentration of volatile oils was higher in the temperate zone.
\end{abstract}

Keywords: Acca sellowiana; linoleic acid; nutraceutical foods; phenols in jam; volatile oil

\section{Introduction}

Feijoa fruit has several human health properties (Weston, 2010), such as antidepressant (Mahmoudi et al., 2015), and a reducer of toxicity by Mercury in blood (Tortora et al., 2019). The feijoa is a new fruit tree crop cultivated in tropical highlands of Mexico (González-García et al., 2018). Usually, the feijoa is grown in areas cooler than tropical highlands, for example, in New Zealand (Sun-Waterhouse et al., 2013), or Russia (Belous et al., 2014).

The processing of feijoa into new functional foods is popular in New Zealand, Australia, Colombia (Zotarelli et al., 2012), and Brazil (Amaral et al., 2019). It has been initiated in Mexico the processing of feijoa then studies on changes in total phenols and antioxidant capacity in processed fruit is required to improve benefits for humans, and to conserve bioactive compounds.

Received: 02 Jul 2020. Received in revised form: 12 Jan 2021. Accepted: 15 Jan 2021. Published online: 21 Jan 2021.

From Volume 49, Issue 1, 2021, Notulae Botanicae Horti Agrobotanici Cluj-Napoca journal will use article numbers in place of the traditional method of continuous pagination through the volume. The journal will continue to appear quarterly, as before, with four annual numbers. 
There is little information regarding changes in antioxidant content after feijoa is transformed into jam, and dehydrated fruit (Buratto et al., 2019). Beyhan et al. (2010), showed that air-dried feijoa fruit had adequate antioxidant capacity, but losses in bioactive compounds by this process were not specifically mentioned.

Essential oils are volatile substances of an organic nature, responsible for the aroma of plants, and they have medicinal properties. The volatiles of the feijoa skin have antimicrobial and pharmacological properties (Smeriglio et al., 2019). Some of the volatile compounds in feijoa are methyl and ethyl benzoates, which represent approximately $90 \%$ of the volatile fraction and are responsible for the aroma of the fruit (Binder and Flath, 1989). The production of essential oils in the skin of the feijoa is affected by environmental conditions (Basile et al., 2010; Smeriglio et al., 2019), and by the cultivars (Peng et al., 2019). It is unknown the yield capacity of the feijoa skin to produce essential oils when it is grown in tropical highland conditions.

The composition of the oils in the seeds of feijoa may vary according to the geographical origin of production (Weston, 2010).

In the present study, the antioxidant activity and total phenols and total flavonoids in dehydrated fruit, and jam were evaluated. The oils in the seeds, and essential oil in the skin of feijoa fruit were also determined.

\section{Materials and Methods}

\section{Plant material and growth conditions}

Feijoa (Acca sellowiana (O. Berg) Burret) fruit was collected at physiological maturity in Huatusco, Veracruz, Mexico, in July 2015 to study the effects of dehydration. The fruit was harvested from eight-year-old trees propagated by seed. The trees were under rain-fed conditions. The trees were established in a $4 \times 4 \mathrm{~m}$ planting arrangement in a tropical highland at $1950 \mathrm{~m}$ elevation $\left(19^{\circ} 11^{\prime} 12.48^{\prime \prime} \mathrm{N}, 97^{\circ} 11^{\prime} 13.75^{\prime \prime} \mathrm{W}\right)$, with average annual rainfall and temperature of $1825 \mathrm{~mm}$ and $17^{\circ} \mathrm{C}$, respectively. On these trees Feijoa fruit was also collected for the essential oil determination. In addition, fruit were collected in an orchard located in a temperate zone in Chapingo, Texcoco, State of Mexico. This orchard had feijoa seedlings at $4 \mathrm{x} 4 \mathrm{~m}$. This orchard was located at $2250 \mathrm{~m}\left(19^{\circ} 29^{\prime} 05^{\prime \prime} \mathrm{N}, 98^{\circ} 53^{\prime} 11^{\prime \prime} \mathrm{W}\right)$. The average annual temperature and rainfall was $16^{\circ} \mathrm{C}$ and rainfall $618 \mathrm{~mm}$, respectively. The trees had irrigation in Spring and Summer. For the essential oil determination, two fruits per each of five trees in each of the two different orchards were used in July 2017.

\section{Dehydrated fruit}

Fruit was lyophilized (Labconco $\left.0^{\circ} 4.5\right)$ for $9 \mathrm{~h}$ at a pressure of $332 \mathrm{Mbar}^{*} 10^{-3}$ and at $-41^{\circ} \mathrm{C}$ or dehydrated in an air convection oven (Sedona Combo-SD-P9150-F) at $60 \mathrm{C}$ for $8 \mathrm{~h}$ and afterwards at $40{ }^{\circ} \mathrm{C}$ for $24 \mathrm{~h}$. In each case, 50 fruits were used.

Thus, in a batch of 30 fruit replicated five times in each of the two treatments, $0.500 \mathrm{~g}$ of a mix of dehydrated pulp or skin fruit were weighed, subsequently grounded and placed in falcon tubes, mixed with 10 $\mathrm{mL}$ of a methanol/water solution (4: 1, v/v). This mixture was homogenized in a vortex at $3000 \mathrm{rpm}, 3 \mathrm{~min}$, and subsequently the $\mathrm{pH}$ was adjusted to $3 \pm 0.05$ with $5 \% \mathrm{HCl}$ solutions. The mixture was stirred for 15 minutes (Ultrasonic Cleaner 8890 , Cole-Parmer) and stirred $(30 \mathrm{~min})$ at $27^{\circ} \mathrm{C}$. Finally, it was centrifuged (2500 rpm, $15 \mathrm{~min}$ ) (SOLBAT J-600, Mexico). The supernatant was made up to $10 \mathrm{~mL}$ with the methanol/water solution $(4: 1, \mathrm{v} / \mathrm{v})$. Total phenols, total flavonoids and antioxidant capacity were quantified with the obtained solutions.

\section{Jam elaboration}

Jam was elaborated from a quantity of $500 \mathrm{~g}$ of fruit (skin + pulp). Half $(250 \mathrm{~g})$ was chopped into pieces, and the rest was ground in a blender (Oster 4125). The blended material was mixed with the fruit pieces and emptied into a pewter pot. Sugar was added, together with $1 \mathrm{~g}$ of high-methoxyl pectin (Dupont ${ }^{\circ}$ ); this mixture was heated to a temperature of $60^{\circ} \mathrm{C}$. The fruit:sugar percentage was $60: 40$. Five replications were made. For 
the extraction, $1 \mathrm{~g}$ of feijoa jam was weighed and all the steps for extraction were as mentioned before. Total phenols, total flavonoids and antioxidant capacity were quantified.

The vitamin $\mathrm{C}$ in the jam was determined by the volumetric method (Association of Official Analytical Chemists [AOAC], 1990). An extractive solution was prepared by mixing $7.5 \mathrm{~g}$ of metaphosphoric acid, 200 $\mathrm{mL}$ of distilled water, and $20 \mathrm{~mL}$ of acetic acid. Jam samples were analyzed in triplicate for each of the five jam replications.

\section{Assays of bioactive compounds}

The content of total phenolic compounds in the extracts of the feijoa tissues was determined using the Folin-Ciocalteu reagent (Singleton and Rossi, 1965). Gallic acid was used for constructing the standard curve at $765 \mathrm{~nm}$. The polyphenol concentration in the samples was derived from a standard curve of gallic acid. The total flavonoids ( $\mathrm{mg} \mathrm{EC} \mathrm{g}^{-1} \mathrm{FW}$ ) were determined according to Kubola and Siriamornpun (2011). The catechin calibration curve to determine total flavonoid content $\left(\mathrm{mg} \mathrm{EC} \mathrm{g}^{-1} \mathrm{DW}\right)$ was in a range from 5.8 to $290 \mu \mathrm{g} \mathrm{mL}$ ${ }^{1}$. These evaluations were adapted to microplates.

For determination of DPPH (2,2-diphenyl-1-picrylhydrazyl) ( $\mu$ mol ET $\left.\mathrm{g}^{-1} \mathrm{DW}\right)$ radical scavenging activity, a mixed solution of $2.5 \mathrm{mg}$ of DPPH radical with $100 \mathrm{~mL}$ of methanol was used (Cheng et al., 2006). For the reaction, $3.9 \mathrm{~mL}$ of DPPH radical was placed in a test tube, and $100 \mu \mathrm{L}$ of extract was added. The mixture was shaken and kept for 30 minutes in the dark at room temperature. Absorbance was measured at $517 \mathrm{~nm}$. Results were calculated in Trolox (6-hydroxy-2,5,7,8-tetramethylchroman-2-carboxylic acid) equivalent antioxidant capacity. Radical-scavenging activity (RSA) was calculated as a percentage of DPPH decoloration, using the equation RSA\% $=(1-\mathrm{Am} / \mathrm{Ar}) 100$, where Am is the absorbance of the solution when the sample extract is added at a particular level, and $\mathrm{Ar}$ is the absorbance of the DPPH as control.

The inhibitory activity of the ABTS ([2,2'-azino-bis (3-ethylbenzothiazoline-6-sulphonic acid) ( $\mu \mathrm{mol}$ equiv Trolox g ${ }^{-1} \mathrm{DW}$ ) cation radical on the extracts was measured according to Re et al. (1999). The ABTS was prepared by mixing $7 \mathrm{mM} \mathrm{ABTS}$ with $2.45 \mathrm{mM} \mathrm{K} \mathrm{S}_{2} \mathrm{O}_{8}$. The mixture was kept for 16 hours at room temperature in the dark until it reached a stable state. Each day of the analysis, the ABTS solution was diluted with distilled water to an absorbance of $0.700 \pm 0.02$ at a wavelength of $734 \mathrm{~nm}$. A mixture was made of $980 \mu \mathrm{L}$ of ABTS solution and $20 \mu \mathrm{L}$ of the fruit pulp, and absorbance was determined at $734 \mathrm{~nm}$ after 8 minutes using a Du 7500 UV spectrophotometer (Beckman). The blank was $80 \%$ methanol. A calibration curve was plotted using Trolox as the standard (within a range of 7.5 to $65 \mathrm{mM})$ in a methanol/water solution $(80: 20 \mathrm{v} / \mathrm{v})$, under the conditions described above.

The FRAP (Ferric Reducing Antioxidant Power) assay ( $\mu$ mol equiv Trolox $\mathrm{g}^{-1} \mathrm{DW}$ ) was carried out according to Benzie and Strain (1996) and adapted to a 96-well microplate. Each well contained $20 \mu \mathrm{L}$ of the tissue extracts, $180 \mu \mathrm{L}$ of the FRAP solution, and $60 \mu \mathrm{L}$ of distilled water. The plate was subsequently shaken for $30 \mathrm{~min}$, and absorbance was measured at $600 \mathrm{~nm}$ in a microplate reader (Synergy 2 Microplate reader, Biotek International, software Gen5). A blank of $260 \mu \mathrm{L}$ of the FRAP solution was used. The Trolox calibration curve was in a range of 3.8 to $46.0 \mu \mathrm{M}$. The reducing power of the feijoa extracts was estimated from the equation obtained by the curve.

Seed oils

A total of $30 \mathrm{~g}$ of seeds was extracted from randomly harvested fruit. Oil from the seeds was obtained using a Soxhlet distillation instrument (Meyer and Terry, 2008). The oil from the seeds was derivatized to fatty acid methyl esters (FAMEs), which were analysed using an Agilent 6890 gas chromatograph with a flame ionization detector (FID) using an AT-Silar column (López-Yerena et al., 2018).

\section{Essential oils in the fruit skin}

It was isolated from the fruit skin by hydro distillation using the Clevenger device (Shaw et al., 1983). There were 10 replication fruit per each of the two studied zone. The essential oil was dissolved in HPLC grade 
hexane at a $1 / 1000$ ratio and $1 \mu \mathrm{L}$ was injected into GC (7890 A, Agilent Technologies, Palo Alto, CA, USA) coupled with MS (Agilent 240) with ion trap detector. A VF-5 MS column (5\% inert phenylmethylpolysiloxane $30 \mathrm{~m} \times 250 \mu \mathrm{m} \times 0.25 \mu \mathrm{m}$ ). Oven temperature was set to $60^{\circ} \mathrm{C}$ for $4 \mathrm{~min}$, then to $150^{\circ} \mathrm{C}$ at $5^{\circ} \mathrm{C} / \mathrm{min}$, to $170^{\circ} \mathrm{C}$ at $2^{\circ} \mathrm{C} / \mathrm{min}$, and finally to $270^{\circ} \mathrm{C}$ at $15^{\circ} \mathrm{C} / \mathrm{min}$ for $5 \mathrm{~min}$. Helium was used as carrier gas at a flow rate of $1.0 \mathrm{~mL} / \mathrm{min}$. An n-alkane mixture $\left(\mathrm{C} 8-\mathrm{C} 20\right.$, Sigma $\left.{ }^{\circ}\right)$ was injected under the same conditions as the sample. The retention times of the sample components and n-alkane blend were used to calculate the Linear Retention Index (LRI) (Van Den Dool and Kratz, 1963). Compounds were identified by comparing the calculated LRI with the LRI reported in the webbook of National Institute of Standards and Technology (NIST).

\section{Data analysis}

For the dehydration fruit treatments, and jam data, the standard errors were determined. The fatty acids in the seeds, and the essential oils in the fruit skin of two different zones are expressed in \%. The Infostat software was used to analyse all the data (Di Rienzo et al., 2016).

\section{Results}

\section{Dehydrated fruit}

In dehydrated or lyophilized fruit, the skin had almost two- or three-times higher contents of total phenols, total flavonoids, and antioxidant capacity obtained by DPPH, ABTS, and FRAP than the pulp (Table 1). Sun-Waterhouse et al. (2013) noted that the skin of feijoa had more bioactive compounds than the pulp. The total flavonoid content in the pulp of the lyophilized feijoa (Table 1) was three times higher than the values reported by Pasquariello et al. (2015).

Table 1. Content of total phenols (TP), total flavonoids (TF), and antioxidant capacity by ABTS, DPPH, and FRAP in skin and pulp of feijoa after lyophilization and dehydration by air convection.

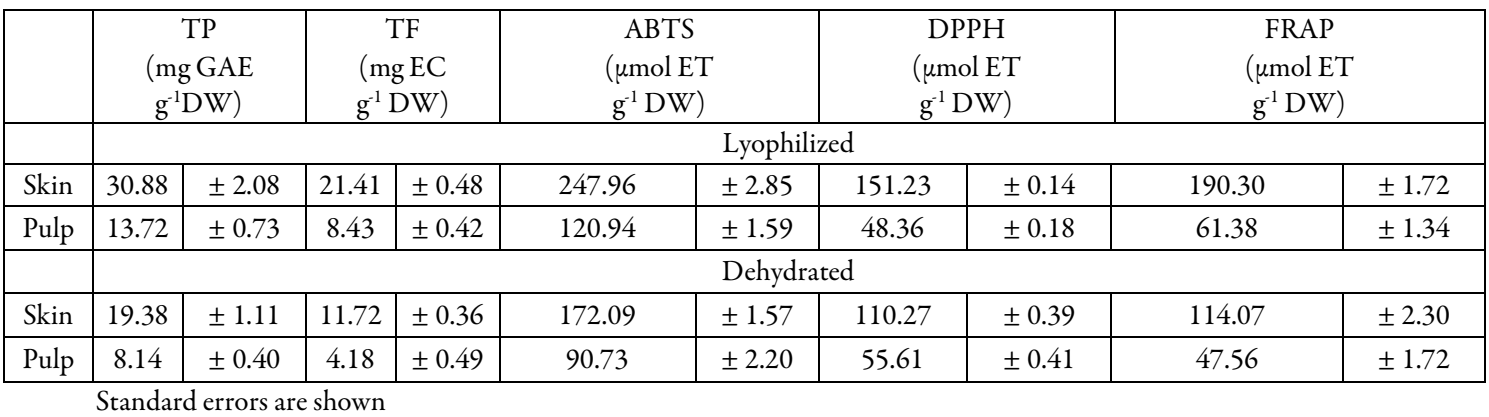

When the values of antioxidant capacity in the feijoa pulp were transformed into fresh weight, they averaged for ABTS $19.92 \pm 0.27 \mu \mathrm{mol} \mathrm{ET} \mathrm{g}{ }^{-1} \mathrm{FW}$; this antioxidant capacity was similar to macadamia nut (Macadamia integrifolia), caimito (Pouteria caimito), arazá (Eugenia estipitata), and umaní (Poraqueiba serícea) (Contreras-Calderón et al., 2011). In the skin, the antioxidant activity values obtained by ABTS (54.07 $\left.\mu \mathrm{mol} \mathrm{ET} \mathrm{g}{ }^{-1} \mathrm{FW}\right)$ and FRAP $\left(41.63 \mu \mathrm{mol} \mathrm{ET} \mathrm{g}{ }^{-1} \mathrm{FW}\right)$ were higher than those determined in the skin of naranjilla (Solanum quitoense) and pejibaye (Bactris gasipaes) (Contreras-Calderón et al., 2011).

The feijoa dehydrated by convection with respect to lyophilized had a reduction in total phenols and total flavonoids in the skin of about $37 \%$ and $45 \%$, respectively, and in the pulp, the reduction averaged $45 \%$ for phenols and flavonoids (Table 1). Antioxidant capacity also declined an average of $32 \%$ in the skin and 20\% in the pulp (Table 1). In contrast, in other studies (Beyhan et al., 2010), the antioxidants in the feijoa pulp dehydrated by convention were less affected. Recent studies shown that the spray drying method is adequate to 
conserve bioactive compounds in feijoa used as powder (Buratto et al., 2019). A convective multi-flash drying process for producing dehydrated crispy feijoa fruits could be also used (Zotarelli et al., 2012).

The conservation of bioactive compounds in the feijoa is required because the raw material must contain high content of bioactive compounds for elaboration of innovative feijoa products, such as those that stimulate immunity activity with isoflavonoids (Lapčík et al., 2005), sun screen formulations (Ebrahimzadeh et al., 2014), and medications to prevent gastritis and ulcers (Monforte et al., 2014).

Jam

The total phenols and flavonoids in the extract of jam (skin + pulp) (Table 2) compared to the lyophilized pulp declined $52 \%$ on average (Tables 1 and 2). The reduction in antioxidant capacity averaging ABTS, DPPH, and FRAP was $72 \%$. (Tables 1,2$)$. The concentration of vitamin $C$ also declined $\left(0.11 \mathrm{mg} \mathrm{g}^{-1}\right.$ $\mathrm{DW}$ ). For example, in lyophilized feijoa skin, the values of vitamin $\mathrm{C}$ were about $0.59 \mathrm{mg} \mathrm{g}^{-1} \mathrm{DW}$ (GonzálezGarcía et al., 2018). The processing significantly affects the concentration of vitamin C in guava jam (OrdóñezSantos and Vazques-Riascos, 2012). Methods of preparing feijoa jam without a significant reduction in bioactive compounds and vitamin $\mathrm{C}$ are required. For example, high pressure processing (Srinivas et al., 2018).

Table 2. Total phenols (TP), total flavonoids (TF), and antioxidant capacity by ABTS, DPPH, FRAP, and content of vitamin $\mathrm{C}$ in feijoa jam. Mean \pm standard errors are shown

\begin{tabular}{|c|c|}
\hline TP $\left(\mathrm{mg} \mathrm{GAE} \mathrm{g}^{-1} \mathrm{FW}\right)$ & $1.86 \pm 0.14$ \\
\hline $\mathrm{TF}\left(\mathrm{mg} \mathrm{EC} \mathrm{g}^{-1} \mathrm{FW}\right)$ & $0.47 \pm 0.05$ \\
\hline $\mathrm{ABTS}\left(\mu \mathrm{mol} \mathrm{ET} \mathrm{g}^{-1} \mathrm{FW}\right)$ & $1.43 \pm 0.14$ \\
\hline $\mathrm{DPPH}\left(\mu \mathrm{mol} \mathrm{ET} \mathrm{g}^{-1} \mathrm{FW}\right)$ & $7.71 \pm 0.56$ \\
\hline FRAP $\left(\mu \mathrm{mol} \mathrm{ET} \mathrm{g}{ }^{-1} \mathrm{FW}\right)$ & $11.75 \pm 1.07$ \\
\hline Vitamin C $\left(\mathrm{mg} \mathrm{g}^{-1} \mathrm{DW}\right.$ & $0.11 \pm 0.00$ \\
\hline
\end{tabular}

\section{Oil content of the seeds}

The oil content was $0.23 \%$, and this value was two times lower than that reported by Andrade et al. (2012) in Brazil with feijoa trees grown under temperate conditions. Linoleic acid achieved the highest value at $46 \%$ (Table 3), and Andrade et al. (2012) also found linoleic acid (84\%) as the main fatty acid in feijoa seeds. This study confirmed that linoleic acid is the main fatty acid in feijoa seeds Palmitic acid appeared at $21 \%$, and oleic acid at 19\% (Table 3). Lower values were reported for oleic acid (Andrade et al., 2012) in comparison with those found in the present study. Most of the fatty acids (69\%) in the seeds were polyunsaturated. There is no information on whether the unsaturated lipids of the feijoa seeds may become bioavailable for humans (Zhu, 2018). Behenic acid that is a cholesterol-raising saturated fatty acid in humans (Cater and Denke, 2001) was also detected in the seeds but in small amounts (0.91\%).

Table 3. Fatty acids (\%) in seeds of feijoa fruit

\begin{tabular}{|c|c|c|}
\hline \multicolumn{2}{|c|}{ Fatty acids } & $(\%)$ \\
\hline Palmitic & $\mathrm{C} 16: 0$ & 20.86 \\
\hline Palmitoleic & C16:1 & 0.48 \\
\hline Stearic & C18:0 & 2.77 \\
\hline Oleic & C18:1w9 & 18.57 \\
\hline Linoleic & $\mathrm{C} 18: 2 \omega 6$ & 46.23 \\
\hline Linolenic & $\mathrm{C} 18: 3 \omega 9,12,15$ & 3.69 \\
\hline Behenic & C20:0 & 0.91 \\
\hline
\end{tabular}

\section{Essential oil}

The yield of essential oil obtained from feijoa skin of Huatusco and Chapingo were $0.37 \% \pm 0.00$ and $0.53 \% \pm 0.00$, respectively. Low recovery of essential oil was also obtained in New Zealand (Shaw et al., 1983) 
but in Italy have reported until $0.8 \%$ (Smeriglio et al., 2019). There were 31 compounds detected, and the most abundant in the fruit of both zones were 3-hexen-1-yl benzoate (15.4\%), elixene (9.8\%), spathulenol (8.8\%), D-germacrene (8.3\%), and alpha-cadinol (6.6\%) (Table 4). Binder and Flath (1989) reported 3-hexen-1-yl benzoate, elixene and $\mathrm{D}$-germacrene, although not as major components. Two important volatile components of feijoa fruit are methyl benzoate and ethyl benzoate (Smeriglio et al., 2019). These compounds were identified in the present study with less of $1 \%$, and methyl benzoate was not found in the feijoa harvested in the tropical highland. The 3-hexen-1-yl benzoate belongs to the family of benzoic esters like those two compounds, and should play an aromatic role. Caryophyllene (5.3\%) (Table 4) was also detected in feijoa fruit cultured in Morroco (Elfarnini et al., 2018), and it is a natural bicyclic sesquiterpene present in many essential oils. Saj et al (2008), reported that feijoa essential oil has a broad spectrum of antibacterial and antifungal activity mainly due to caryophyllene oxide. Another compound identified in the fruit of both zones was spathulenol that in vitro is potent against the multi-drug-resistant Mycobacterium tuberculosis (Dzul-Beh et al., 2019). Selinene was a major component in the feijoa skin in Italy (Smeriglio et al., 2019) but in our work it was not detected. It was observed that the fruits collected in the tropical highland (Huatusco) had 26 components, and the fruits from the temperate zone (Chapingo) achieved 31. The essential oil recovery was also lower in the fruit skin harvested in the tropical highland.

The type of essential oils that predominated in the skin of the fruit were terpenoids with $71 \%$ in the temperate zone (Chapingo), and 69\% in the tropical highland (Huatusco). Binder and Flath (1989) reported $53 \%$ terpenoids in feijoa skin produced in USA. In both types of fruit zone, the aromatic esters represented about the $19 \%$ of the identified components.

Table 4. Chemical composition of essential oils of the skin of the feijoa fruit produced in a tropical highland (Huatusco), and in a temperate zone (Chapingo). Calculated retention index (RI), formula, and molecular weight $(\mathrm{MW})$ of compounds are included.

\begin{tabular}{|c|c|c|c|c|c|c|}
\hline No. Compound & IR & Formula & MW & Compound & $\begin{array}{c}\text { Chapingo } \\
(\%)\end{array}$ & $\begin{array}{c}\text { Huatusco } \\
(\%)\end{array}$ \\
\hline 1 & 986 & & & No name & 0.8 & 0.5 \\
\hline 2 & 1037 & $\mathrm{C} 10 \mathrm{H} 16$ & 136 & trans-beta-ocimene & 0.8 & \\
\hline 3 & 1048 & $\mathrm{C} 10 \mathrm{H} 16$ & 136 & beta-ocimene. & 0.6 & 0.4 \\
\hline 4 & 1097 & $\mathrm{C} 8 \mathrm{H} 8 \mathrm{O} 2$ & 136 & methyl benzoate & 0.4 & \\
\hline 5 & 1101 & $\mathrm{C} 10 \mathrm{H} 18 \mathrm{O}$ & 154 & Linalool. (M) & 5.7 & 2.5 \\
\hline 6 & 1174 & C9H10O2 & 150 & ethyl benzoate & 0.7 & 0.4 \\
\hline 7 & 1187 & $\mathrm{C} 10 \mathrm{H} 18 \mathrm{O} 2$ & 170 & $\begin{array}{c}\text { butanoic acid, 4-hexen-1-yl } \\
\text { ester }\end{array}$ & 0.7 & 0.7 \\
\hline 8 & 1198 & $\mathrm{C} 10 \mathrm{H} 18 \mathrm{O}$ & 154 & alpha-terpineol & 0.6 & 0.4 \\
\hline 9 & 1294 & $\mathrm{C} 11 \mathrm{H} 22 \mathrm{O}$ & 170 & 2-undecanone & 2.4 & 1.8 \\
\hline 10 & 1351 & $\mathrm{C} 15 \mathrm{H} 24$ & 204 & alpha-cubebene $(S)$ & 1.1 & 0.9 \\
\hline 11 & 1389 & $\mathrm{C} 15 \mathrm{H} 24$ & 204 & (-)-beta-bourbonene & & 0.4 \\
\hline 12 & 1393 & $\mathrm{C} 15 \mathrm{H} 24$ & 204 & $\beta$-elemene & 1.8 & \\
\hline 13 & 1413 & $\mathrm{C} 15 \mathrm{H} 24$ & 204 & $\alpha$-gurjunene & 0.8 & \\
\hline 14 & 1425 & $\mathrm{C} 15 \mathrm{H} 24$ & 192 & Caryophyllene & 5.3 & 5.3 \\
\hline 15 & 1441 & $\mathrm{C} 12 \mathrm{H} 16 \mathrm{O} 2$ & 204 & $\begin{array}{l}\text { 1-butanol 3-methyl- } \\
\text { benzoate }\end{array}$ & & 1.3 \\
\hline 16 & 1461 & $\mathrm{C} 15 \mathrm{H} 24$ & 204 & Humulene & 3 & 3.1 \\
\hline 17 & 1466 & $\mathrm{C} 15 \mathrm{H} 24$ & 204 & Alloaromadendrene & 0.7 & 0.7 \\
\hline 18 & 1486 & $\mathrm{C} 15 \mathrm{H} 24$ & 204 & D-germacrene & 8.6 & 8.04 \\
\hline 19 & 1488 & $\mathrm{C} 15 \mathrm{H} 24$ & 204 & $\beta$-cubebene & 8.5 & \\
\hline 20 & 1497 & $\mathrm{C} 15 \mathrm{H} 24$ & 204 & Viridiflorene & 3.5 & 4.5 \\
\hline 21 & 1502 & $\mathrm{C} 15 \mathrm{H} 24$ & 204 & Elixene & 8.7 & 10.9 \\
\hline 22 & 1505 & $\mathrm{C} 15 \mathrm{H} 24$ & 204 & alpha-farnesene & 1.3 & 0.2 \\
\hline
\end{tabular}




\begin{tabular}{|c|c|c|c|c|c|c|}
\hline 23 & 1522 & $\mathrm{C} 15 \mathrm{H} 24$ & 204 & $\delta$-cadinene & 3.4 & 3.6 \\
\hline 24 & 1526 & $\mathrm{C} 15 \mathrm{H} 22$ & 202 & trans-calamenene & 2.9 & 4 \\
\hline 25 & 1574 & $\mathrm{C} 13 \mathrm{H} 16 \mathrm{O} 2$ & 204 & 3-hexen-1-yl benzoate & 17.7 & 13.2 \\
\hline 26 & 1582 & $\mathrm{C} 15 \mathrm{H} 24 \mathrm{O}$ & 220 & Spathulenol & 8.6 & 9 \\
\hline 27 & 1589 & $\mathrm{C} 14 \mathrm{H} 20 \mathrm{O} 2$ & 220 & benzoic acid hept-2-yl ester & & 6.7 \\
\hline 28 & 1592 & $\mathrm{C} 15 \mathrm{H} 26 \mathrm{O}$ & 222 & Viridiflorol & 4.05 & 5.5 \\
\hline 29 & 1602 & $\mathrm{C} 15 \mathrm{H} 26 \mathrm{O}$ & 222 & Ledol & & 2.2 \\
\hline 30 & 1637 & & & No name & 1.5 & 6.2 \\
\hline 31 & 1659 & $\mathrm{C} 15 \mathrm{H} 26 \mathrm{O}$ & 222 & alpha-cadinol & 5.7 & 7.5 \\
\hline
\end{tabular}

\section{Conclusions}

The feijoa fruit dehydrated by a conventional air dehydrator lost $45 \%$ of its phenols and flavonoids. Other systems to dehydrated feijoa fruit must be tested. Jam showed the greatest reduction in bioactive compounds. Thus, the feijoa jam processing requires cook novelties to conserve bioactive compounds. The main oil in feijoa seeds was linoleic acid. The main essential oils in the fruit skin were 3-hexen-1-yl benzoate, elixene, and spathulenol. The skin of feijoa, contains essential oils and other chemical properties that requires evaluations in the improving of the human health. The essential oil concentration in the feijoa skin produced in tropical highlands may be lower than in temperate zones. This is the first work showing the essential oils of feijoa produced in Mesoamerica.

\section{Authors' Contributions}

JGC-C: author of the article, planning of the research, and data analysis. FF: revision and critical revision, and data analysis. DG-R: preparation of samples in the laboratory and planning of the research. KEGG, and JMM-H: laboratory data collection, and laboratory analysis.

All authors read and approved the final manuscript.

\section{Acknowledgements}

This work was funded by The Autonomous University of Chapingo, Mexico.

\section{Conflict of Interests}

The authors declare that there are no conflicts of interest related to this article.

\section{References}

Amaral FM, Southgatea ANN, Komatsu RA, Scheuer PM, Maresch GA, da Silva JC (2019). Acca sellowiana: Physicalchemical-sensorial characterization and gastronomic potentialities. International Journal of Gastronomy and Food Science 17:100159. https://doi.org/10.1016/j.ijgfs.2019.100159

Andrade JMDM, Marin R, Apel MA, Raseira MDCB, Henriques AT (2012). Comparison of the fatty acid profiles of edible native fruit seeds from southern Brazil. International Journal of Food Properties 15(4):815822. https://doi.org/10.1080/10942912.2010.503355 
AOAC (1990). Association of Official Analytical Chemists. Official methods of analysis of AOAC international. Washington, D. C. USA. Retrieved 2015 June 20 from http://www.fao.org/3/a-y4705e/y4705e24

Basile A, Botta B, Bruno M, Rigano D, Sorbo S, Conte B, Rosselli S, Senatore F (2010). Effects of air pollution on production of essential oil in Feijoa sellowiana Berg. grown in the 'Italian Triangle of Death'. International Journal of Environment and Health 4(2-3):250-259. https://doi.org/10.1504/ijenvh.2010.033712

Belous O, Omarov M, Omarova Z (2014). Chemical composition of fruits of a feijoa (F. sellowiana) in the conditions of subtropics of Russia. Slovak Journal of Food Sciences 8(1):119-123. https://doi.org/10.5219/358

Benzie IFF, Strain JJ (1996). The ferric reducing ability of plasma (FRAP) as a measure of "antioxidant power": the FRAP assay. Analytical Biochemistry 239(1):70-76. https://doi.org/10.1006/abio.1996.0292

Beyhan Ö, Elmastaş M, Gedikli F (2010). Total phenolic compounds and antioxidant capacity of leaf, dry fruit and fresh fruit of feijoa (Acca sellowiana, Myrtaceae). Journal of Medicinal Plants Research 4(11):10651072. https://doi.org/10.5897/JMPR10.008

Binder RG, Flath RA (1989). Volatile components of pineapple guava. Journal of Agricultural and Food Chemistry 37(3):734-736. https://doi.org/10.1021/jf00087a034

Buratto AP, Carpes-Teresinha S, Pereira-Andrade E, Diedrich C, Oldoni-Cadorin TL, da Silva-Dangui L (2019). Effect of drying method in the maintenance of bioactive compounds and antioxidant activity of Feijoa pulp (Acca sellowiana). The Electronic Journal of Chemistry 11(6): 386-393. https://doi.org/10.17807/orbital.v11i6.1223

Cater NB, Denke MA (2001). Behenic acid is a cholesterol-raising saturated fatty acid in humans. The American Journal of Clinical Nutrition 73 (1):41-44. https://doi.org/10.1093/ajcn/73.1.41

Cheng Z, Moore J, Yu L (2006). High-throughput relative DPPH radical scavenging capacity assay. Journal of Agricultural and Food Chemistry 54(20):7429-7436 https://doi.org/10.1021/jf0611668

Contreras-Calderón, Calderón-Jaimes L, Guerra- Hernández E, García-Villanova B (2011). Antioxidant capacity, phenolic content and vitamin $\mathrm{C}$ in pulp, peel and seed from 24 exotic fruits from Colombia. Food Research International 44:2047-2053. https://doi.org/10.1016/j.foodres.2010.11.003

Dzul-Beh ADJ, Sosa KG, Uc-Cachón AH, Bórquez, J, Loyola LA, Barrios-García HB, ... Molina-Salinas GM (2019). In vitro growth inhibition and bactericidal activity of spathulenol against drug-resistant clinical isolates of Mycobacterium tuberculosis. Brazilian Journal of Pharmacognosy 29:798-800. https://doi.org/10.1016/j.bjp.2019.06.001

Di Rienzo JA, Casanoves F, Balzarini MG, González L, Tablada M, Robledo CW (2016). InfoStat versión 2016. Grupo InfoStat, FCA, Universidad Nacional de Córdoba, Argentina. Retrieved 2016 January 14 from https://www.infostat.com.ar/

Ebrahimzadeh MA, Enayatifard R, Khalili M, Ghaffarloo M, Saeedi M, Charati JY (2014). Correlation between sun protection factor and antioxidant activity, phenol and flavonoid contents of some medicinal plants. Iranian Journal of Pharmaceutical Research 13(3):1041-1047.

Elfarnini M, Abdel-hamid AA, Achir M, Jamaleddine J, Blaghen M (2018). Volatile compounds in the skin essential oil of Moroccan Feijoa sellowiana. European Journal of Medicinal Plants 23(2):17. https://doi.org/10.9734/ejmp/2018/40817

González-García KE, Guerra-Ramírez D, del Ángel-Coronel OA, Cruz-Castillo JG (2018). Physical and chemical attributes of feijoa fruit in Veracruz, Mexico. Revista Chapingo Serie Horticultura 24(1):5-12. https://doi.org/10.5154/r.rchsh.2017.01.006

Kubola J, Siriamornpun S (2011). Phytochemicals and antioxidant activity of different fruit fractions (peel, pulp, aril and seed) of Thai gac (Momordica cochinchinensis Spreng). Food Chemistry 127(3):1138-1145. https://doi.org/10.1016/j.foodchem.2011.01.115

Lapčík O, Klejdus B, Kokoška L, Davidová M, Afandi K, Kubáň V, Hampl R (2005). Identification of isoflavones in Acca sellowiana and two Psidium species (Myrtaceae). Biochemical Systematics and Ecology 33(10):983-992. https://doi.org/10.1016/j.bse.2005.03.007

López-Yerena A, Guerra-Ramírez D, Jácome-Rincón J, Espinosa-Solares T, Reyes-Trejo B, Famiani F, Cruz-Castillo JG (2018). Initial evaluation of fruit of accessions of Persea schiedeana Nees for nutritional value, quality and oil extraction. Food Chemistry 245:879-884. https://doi.org/10.1016/j.foodchem.2017.11.088

Mahmoudi M, Ebrahimzadeh MA, Abdi M, Arimi Y, Fathi H (2015). Antidepressant activities of Feijoa sellowiana fruit. European Review for Medical and Pharmacological Sciences 19:2510-2513. 
Meyer MD, Terry LA (2008). Development of a rapid method for the sequential extraction and subsequent quantification of fatty acids and sugars from avocado mesocarp tissue. Journal of Agricultural and Food Chemistry 56:74397445. https://doi.org/10.1021/jf8011322

Monforte MT, Lanuzza F, Mondello F, Naccari C, Pergolizzi S, Galati EM (2014). Phytochemical composition and gastroprotective effect of Feijoa sellowiana Berg fruits from Sicily. Journal of Coastal Life Medicine 2(1):14-21. https://doi.org/10.12980/jclm.2.2014j12

Ordóñez-Santos LE, Vásquez-Riascos AM (2012). Cambios en la concentración de ácido ascorbico en el procesamiento de frutos de guayaba (Psidium guajava L.). [Changes in the concentration of ascorbic acid in the processing of guava fruit (Psidium guajava L.). Vitae 19(1):84-86.

Pasquariello MS, Mastrobuoni F, Di Patre D, Zampella L, Capuano LR, Scortichini M, Petriccione M (2015). Agronomic, nutraceutical and molecular variability of feijoa (Acca sellowiana (O. Berg) Burret) germplasm. Scientia Horticulturae 191:1-9. https://doi.org/10.1016/j.scienta.2015.04.036

Peng Y, Bishop KS, Quek SY (2019). Compositional analysis and aroma evaluation of feijoa essential oils from New Zealand grown cultivars. Molecules 24(11):2-21. https://doi.org/10.3390/molecules24112053

Re R, Pellegrini N, Proteggente A, Pannala A, Yang M, Rice-Evans C (1999). Antioxidant activity applying an improved ABTS radical cation decolorization assay. Free Radical Biology and Medicine 26(9-10):1231-1237. https://doi.org/10.1016/s0891-5849(98)00315-3

Saj OP, Roy RK, Savitha SV (2008). Chemical composition and antimicrobial properties of essential oil of Feijoa sellowiana O. Berg. (pineapple guava). Journal of Pure and Applied Microbiology 2(1):227-230.

Shaw GJ, Ellingham PJ, Birch EJ (1983). Volatile constituents of feijoa-headspace analysis of intact fruit. Journal of the Science of Food and Agriculture 34:743-747. https://doi.org/10.1002/jsfa.2740340712

Singlenton VL, Rossi JA (1965). Colorimetry of total phenolics with phosphomolybdic-phosphotungstic acid reagents. American Journal of Enology and Viticulture 16:144-158.

Smeriglio A, Denaro M, De Francesco C, Cornara L, Barreca D, Bellocco E, ... Trombetta D (2019). Feijoa fruit peel: micro-morphological features, evaluation of phytochemical profile, and biological properties of its essential oil. Antioxidants 8:320. https://doi.org/10.3390/antiox8080320

Srinivas MS, Madhu B, Srinivas G, Jain SK (2018). High pressure processing of foods: A Review. The Andhra Agriculture Journal 65:467-476.

Sun-Waterhouse D, Wang W, Waterhouse GIN, Wadhwa SS (2013). Utilization potential of feijoa fruit wastes as ingredients for functional foods. Food Bioprocess Technology 6:3441-3455. https://doi.org/10.1007/s11947012-0978-3

Tortora F, Notariale R, Maresca V, Good KV, Sorbo S, Basile A, Piscopo M, Manna C (2019). Phenol-rich Feijoa sellowiana (pineapple guava) extracts protect human red blood cells from mercury-induced cellular toxicity. Antioxidants 8:220. https://doi.org/10.3390/antiox8070220

Van Den Dool, H. \& Kratz, P. D. (1963). A generalization of the retention index system including linear temperature programmed Gas-Liquid partition chromatography. Journal of Chromatography 11(3):463-471. https://doi.org/10.1016/S0021-9673(01)80947-X

Weston RJ (2010). Bioactive products from fruit of the feijoa (Feijoa sellowiana, Myrtaceae): A review. Food Chemistry 121:923-926. https://doi.org/10.1016/j.foodchem.2010.01.047

Zotarelli MF, Almeida-Porciuncula BD, Borges-Laurindo J (2012). A convective multi-flash drying process for producing dehydrated crispy fruits. Journal of Food Engineering 108:523-531. https://doi.org/10.1016/j.jfoodeng.2011.09.014

Zhu F (2018). Chemical and biological properties of feijoa (Acca sellowiana). Trends in Food Science and Technology 81:121-131. https://doi.org/10.1016/j.tifs.2018.09.008 
OPEN ACCESS

(c) (2)

The journal offers free, immediate, and unrestricted access to peer-reviewed research and scholarly work. Users are allowed to read, download, copy, distribute, print, search, or link to the full texts of the articles, or use them for any other lawful purpose, without asking prior permission from the publisher or the author.

License - Articles published in Notulae Botanicae Horti Agrobotanici Cluj-Napoca are Open-Access, distributed under the terms and conditions of the Creative Commons Attribution (CC BY 4.0) License. (C) Articles by the authors; UASVM, Cluj-Napoca, Romania. The journal allows the author(s) to hold the copyright/to retain publishing rights without restriction. 